\title{
Quebrando paradigmas do trabalho com leitura e escrita na escola
}

\section{Breaking paradigms of working with reading and writing in school}

https://doi.org/10.34112/2317-0972a2018v36n74p139-143

Marta Cristina Araujo de Oliveira Baroni ${ }^{1}$

BORGES, Carla Luzia Carneiro; CASTRO, Maria Lúcia Souza (Org.). A leitura e a (re) escritura no ensino-aprendizagem de língua portuguesa. Feira de Santana, BA: UEFS Editora, 2016. 304p.

O livro aqui RESENHADo Resulta dos esforços de um Grupo de Trabalho (GT) formado em 2012 na Universidade Federal de Uberlândia. O objetivo do grupo foi o de dialogar com outros pesquisadores e traçar um panorama sobre os estudos e concepções de leitura e escrita desenvolvidos nos espaços escolares do Brasil.

Dividido em onze capítulos, o livro, além de explicitar os trabalhos e ideias apresentados pelos diversos pesquisadores do GT, permite a investigação dos temas e diálogo com eles, todos abordados no encontro realizado na Universidade Federal de Uberlândia (UFU-MG), em 2012. As organizadoras, Carla Luzia Carneiro Borges e Maria Lúcia Souza Castro, tendo em vista os significativos resultados das discussões realizadas no GT, lançaram a proposta de continuidade do diálogo através da presente publicação.

O livro traz a descrição de diversas abordagens práticas de leitura e (re) escrita, realizadas na sala de aula, bem como reflexões teóricas acerca das pesquisas

1. Secretaria Municipal de Educação de Capivari, Capivari, SP, Brasil. 
efetivadas, apresentando concepções comuns sobre o tema e, em outros momentos, divergências - estas, provenientes da formação e das crenças de cada coautor. É unanimemente assumida a concepção do aluno enquanto participante do processo de ensino-aprendizagem, como sujeito ativo, capaz de compreender o que lê e escreve, para quem escreve, onde e com que objetivo o realiza.

Os teóricos que fundamentaram as concepções e ideias defendidas nos diferentes textos em muito se assemelham; nas referências dos artigos aparecem, principalmente, Bakhtin (1999); Chartier (2009); Kleiman (1997); KIoch (2007); Schnewly (2004); Fontana, Goes (1990); Geraldi (1997); Dolz (2010); e Marcuschi (2008).

No primeiro e segundo capítulos do livro, escritos respectivamente por Eliane Machado Pinto e Sinéia Maia Teles Silveira, são descritas as práticas educacionais desenvolvidas pela escola no decorrer de sua história. Essas práticas são caracterizadas como superficiais - em leitura, por exemplo, o leitor se relaciona com o texto com o simples objetivo de decodificar e extrair informações explícitas contidas no mesmo. Silveira tece severas críticas sobre esse tipo de trabalho, destacando que a escola não é incentivadora da leitura; assim, o ensino da leitura não contempla a necessidade de amorosamente formar leitores, mas tão apenas apresentar uma lista de livros que deve ser lida pelos alunos até o final do Ensino Médio.

As práticas de leitura desenvolvidas em sala de aula, segundo Pinto, contribuem para o desinteresse e desmotivação dos alunos, considerando-se que a formação de educandos competentes depende do desenvolvimento de todas as capacidades de leitura que a produção de sentido ao texto exige.

Nesse contexto, destaca-se a importância e relevância de se levar em conta os conhecimentos prévios dos alunos (conhecimento de mundo ou enciclopédico e linguístico), já que a leitura, enquanto processo interativo, somente ocorre mediante a mobilização desses conhecimentos pelo leitor.

Dentro dessa concepção de trabalho com a leitura, o capítulo oito, escrito por Darlan Machado Dorneles, e o nove, por Elisane Regina Cayser e outros, destacam a importância do professor ter um olhar atento tanto para as habilidades necessárias, quanto para as dificuldades envolvidas no ato de escrever, ler e interpretar textos, que os alunos apresentam no decorrer de sua vida acadêmica e depois dela. Dorneles descreve brilhantemente a leitura, quando remete o leitor à concepção de que a mesma não se finda no instante em que se lê, mas que se expande por todo o processo de entendimento que antecede o texto. 
No capítulo três, Cláudia Beatriz de Castro Nascimento Ometto e Rita de Cássia Cristofoleti nos trazem uma reflexão acerca da produção de textos e a reflexividade nas crianças, relatando um estudo realizado com alunos do terceiro ano do Ensino Fundamental I, cujo objetivo foi compreender a relação da mediação realizada pela professora com os processos de elaboração e reelaboração da escrita pelas crianças, com foco na dimensão reflexiva do ato de escrever. As autoras se basearam em teóricos como Vygotsky (1989) e Bakhtin (2003) para delinear os processos de escrita das crianças em sua dimensão reflexiva, dentro de uma perspectiva histórico-cultural de desenvolvimento humano.

Ometto e Cristofoleti descrevem magistralmente que o indivíduo se torna quem ele é no processo de apropriação e de elaboração das formas culturais já consolidadas no grupo social ao qual pertence. Essa constituição se dá por meio das relações com o outro, e da linguagem, a qual se estabelece nas relações sociais, que são determinadas pelos lugares e papéis sociais nelas envolvidos. Segundo essa concepção, a educação escolar e, consequentemente, o professor, são constitutivos do desenvolvimento dos indivíduos. Por conseguinte, dentro desse processo, também da atividade da escrita e da reflexividade, as quais não ocorreriam espontaneamente, sem a mediação do professor.

O papel do professor no processo de ensino-aprendizagem nos remete ao artigo de Andresa Guedes Kaminski Alves e outros, que destaca a importância da formação do professor que irá desenvolver o trabalho pedagógico com a leitura e a escrita - um trabalho que transgrida as barreiras e dogmas existentes dentro das escolas.

As reflexões contidas nos capítulos quatro, cinco e sete, de autoria de Antônia Tatiana Sales dos Santos, Maria Lúcia Souza Castro, George França e Carla Luzia Carneiro Borges, destacam a importância da escrita, ressaltando ser o seu domínio uma condição de inclusão do sujeito no meio social onde vive. Santos, Castro e Borges descrevem sequências didáticas e reflexões sobre a importância do contato com suportes de textos, antes mesmo de a criança chegar à escola. França, por sua vez, delineia atividades no Ensino Médio que possibilitaram aos alunos um relacionamento com textos de literatura, atividades que caminham para uma superação do trabalho pontual e nostálgico dos livros didáticos.

As relações estabelecidas entre leitura e escrita da memória são objeto de discussão de Carla de Quadros no capítulo dez, em que se destaca a relação intrínseca entre escritor-narrador-personagem, constituindo o narrador-leitor, o qual se projeta como devorador da leitura que deve ser realizada com prazer. A autora 
analisou criticamente a obra de três memorialistas - Isaías Alves, Anna Ribeiro de Goés Bittencourt e Eurico Alves Boaventura. Em um dos trechos de sua reflexão, Quadros presenteia o leitor com a seguinte colocação de Paul De Man (1996, p. 282): "Compreende-se, ainda, que o ato de escrever está ligado visceralmente ao ato de ler e isso se torna ainda mais evidente quando se analisam textos elaborados a partir das memórias de leituras".

O capítulo que fecha o livro, escrito por Jesus e Barbosa, relata uma experiência realizada com alunos de Licenciaturas, os quais tiveram seus textos analisados e corrigidos por alunos do curso de Letras. Diante do trabalho desenvolvido, os pesquisadores concluíram que escrever e reescrever ainda é algo que deve ser desenvolvido na universidade. É necessário foco no ensino da linguagem, pois é através dela que o sujeito aprende diversos conceitos que lhe permitem compreender o mundo e com ele interagir.

Encerrando a obra, as organizadoras destacam a importância da continuação de debates e pesquisas em que a língua seja o objeto de estudo, levando para as escolas um trabalho com a leitura e a escrita que seja prazeroso e significativo na constituição do sujeito leitor. Os autores demonstram em suas pesquisas diversos caminhos e possibilidades para realizar esse trabalho, desenvolvendo tanto as habilidades quanto a interação do aluno com o universo letrado. Tais ideias e contribuições são extremamente importantes - devem ser lidas, discutidas e disseminadas nas escolas, pois possibilitarão ao professor refletir, analisar sua prática e romper com rótulos, ideais e paradigmas que engessam seu trabalho. Essas limitações o impedem de desenvolver propostas e métodos de ensino que tornem a leitura e a escrita atividades substanciais e necessárias para conduzir sujeitos a um patamar de saberes mais elevados, constituídos de uma ampla visão de mundo. Desse modo, os trabalhos propostos neste livro sobre as práticas educativas contribuem para que os alunos se tornem críticos e reflexivos sobre suas ações e aquilo que acontece ao seu redor.

Ao realizar a leitura do livro, o leitor se deparará com reflexões, discussões e apontamentos sobre o desenvolvimento da leitura e escrita nas aulas de língua portuguesa em uma perspectiva que contradiz e tenta romper com o trabalho comumente desenvolvido nas escolas. Considero o livro relevante, tanto no meio acadêmico, pois oferece direcionamento para novos questionamentos e pesquisas, quanto para a formação continuada de professores, já que apresenta diversas experiências realizadas em sala de aula. 
SOBRE A AUTORA:

Marta Cristina Araujo de Oliveira Baroni é graduada em Pedagogia (CNEC - Campanha Nacional de Escolas da Comunidade/Unidade Capivari), tem Pós-Graduação em Psicopedagogia Lato Sensu (CNEC - Campanha Nacional de Escolas da Comunidade/Unidade Capivari). É professora Alfabetizadora no Município de Capivari desde 2001, atuando também na área de gestão, tanto na Direção de Escola quanto na Coordenação Pedagógica. Atualmente na Coordenação Pedagógica da EJA - Educação de Jovens e Adultos na Escola Municipal Augusto Castanho. Participa também da formação de professores no município em que atua.

E-mail: maraujosantos@live.com.

Recebido em o6 de fevereiro de 2018 e aprovado em 14 de abril de 2018. 